\title{
A review of penile metastasis
}

\author{
Luigi Mearini, ${ }^{1}$ Renato Colella, ${ }^{2}$ Alessandro Zucchi, ${ }^{1}$ Elisabetta Nunzi, ${ }^{1}$ Carlo Porrozzi, ${ }^{1}$ \\ Massimo Porena ${ }^{1}$ \\ 'Urology Department; ${ }^{2}$ Pathological Anatomy and Histology Department,
University of Perugia, Italy
}

\begin{abstract}
Penile cancer as primary disease is relatively rare in developed countries. The penis is a rare site of metastases in spite of its rich vascularization. Approximately 500 cases have been reported in the literature; almost $70 \%$ of primary lesions are of pelvic origin (from genitourinary or recto-sigmoid primary tumors). We describe a case of penile metastasis from lung cancer. The rarity of the event prompted us to also explore related reviews and discuss the incidence, physiopathology, diagnosis and therapy of penile secondary cancer.
\end{abstract}

\section{Introduction}

Penile cancer is a relatively rare disease in developed countries with an annual incidence of less than 1 case per 100,000 person-years in Western populations. ${ }^{1,2}$ It accounts for up to $10 \%$ of cancers in men in some parts of Asia, Africa and South America.

As primary disease, penile cancer typically occurs in later life, at a mean age of 68 years in the USA. ${ }^{3}$ Factors associated with increased risk of primary penile cancer include low socio-economic status, poor or lack of penile hygiene, phimosis and chronic penile inflammation,

Correspondence: Luigi Mearini, Urology Department, University of Perugia, Sant'Andrea delle Fratte - 06100 Perugia, Italy.

Tel. +39.075.578.4252 - Fax: +39.075.578.4416. E-mail: luigi.mearini@tin.it

Key words: penis, penile metastasis, secondary malignancy, malignant priapism.

Contributions: LM, MP, manuscript conception, design, drafting, final approval; RC, AZ, EN, CP, data acquisition, analysis, interpretation.

Conflict of interests: the authors declare no potential conflict of interests.

Received for publication: 27 March 2012.

Revision received: 2 June 2012.

Accepted for publication: 7 June 2012.

This work is licensed under a Creative Commons Attribution NonCommercial 3.0 License (CC BY-NC 3.0).

(C) Copyright L. Mearini et al., 2012

Licensee PAGEPress, Italy

Oncology Reviews 2012; 6:e10

doi:10.4081/oncol.2012.e10 cigarette smoking, human papillomavirus (HPV) infection and/or multiple sexual partners, and infection by acquired immune deficiency syndrome (AIDS). Each of the tissues in the penis contains several types of cells and different types of penile cancer can develop from each kind of cell.

However, considering the risk factors and causes, almost all penile primary cancers start in the skin cells of the penis. According to histology, squamous cell carcinomas are the most common type of penile cancer, accounting for $93 \%$ of all reported tumors. Typical squamous cell carcinoma accounts for $50-60 \%$ of penile cancer. Verrucous carcinoma is the most frequent subtype of squamous cell carcinoma, followed by condylomatous warty, papillary and basaloid carcinoma. Other epithelial cancers include basal cell and transitional cell carcinomas arising from the urethra. Rare histological types include adenocarcinoma, melanoma and Kaposi sarcoma.

Secondary penile cancer, as a consequence of metastatic disease, is an extremely rare event. This is in spite of the rich vascularization of the penis and the rich vascular communication between penis and the neighboring pelvic organs. Effectively, most cases of secondary penile malignancy have been found to originate from pelvic primary sites, usually associated with disseminated disease. Clinical manifestations of penile metastases vary widely and usually include penile nodules, malignant priapism and skin lesions. Secondary penile cancer is usually a deep disease which does not develop as a superficial skin lesion.

We present an interesting case of penile metastasis as first manifestation of a lung adenocarcinoma. We also review the literature on penile metastases, and discuss its incidence, physio-pathology, diagnosis, therapy and prognosis.

\section{Case Report}

A 62-year old man, an ex-heavy smoker, with diabetes and chronic heart ischemia, presented with a 4-month history of sharp, burning and refractory penile pain in both a flaccid state and erection, associated with hardening of the glans and penile tip and stranguria. Pain had heavily impacting on daily life and sleeping, and had been treated with anti-inflammatory drugs, analgesic and corticosteroid, none of which relieved the pain symptoms. On physical examination, the patient had a normal penile shaft and glans, with pain on palpation of a nodule involving glans, distal urethra and the distal tips of corpora cavernosa, causing distal urethral stricture. Penile ultrasound showed a hypoechoic area of $24 \times 19 \mathrm{~mm}$ involving the glans and corpora cavernosa associated with peripheral hypervascolarity. Magnetic resonance imaging (MRI) scan of the penis was performed. This showed a lesion bilaterally located in the distal corpus cavernosum, with an extension to distal corpus spongiosum. The lesion was characterized by low signal intensity on both T1 and T2 weighted images. After Gadolinium administration it showed prominent contrast enhancement; pelvic MRI was negative.

Given the urgency of the presentation and the presence of urethral 
stricture, after accurate informed consent the patient underwent penile exploration to obtain histopathological diagnosis and urethral clearing: a frozen section of surgical margin showed foci of adenocarcinoma in the corpus cavernosum (Figure 1).

The patient underwent partial amputation with penile resurfacing. Histologically, the nodule was composed of glandular structures lined by atypical cells (Figure 2A and B). Immune-histochemical investigation showed diffuse cellular positivity for cytokeratin 7 and TTF1 (Figure 2C and D) while cells were negative for cytokeratin 20, prostate specific antigen (PSA), PSAP and CDX2. These findings were consistent with the diagnosis of penile metastases of lung adenocarcinoma.

A chest X-ray showed a primary 7-cm right lobe tumor while a bone scan showed multiple metastases to the bones. The patient and his family were counseled extensively on the extent of the disease as well as the treatment options. He was then referred to the Oncology Department for further medical management (carboplatin 600 $\mathrm{mg}+$ pemetrexed $850 \mathrm{mg}+$ dexamethasone $8 \mathrm{mg}$ ).

At 7-month follow up, despite optimal local control, the patient developed a superior vena cava syndrome and died of heart failure.

\section{Review of the literature}

\section{Search strategy}

A literature search was carried out using MEDLINE ${ }^{\circledR} /$ Cochrane libraries from 1940 to date using the following search items: penis, penile metastasis, secondary malignancy, malignant priapism. No language restrictions were imposed. When necessary, we contacted the authors to obtain any relevant information we found to be missing from published papers.

The search included original articles, review articles and editorials and these were reviewed in order to select relevant articles.

In March 2012, the search had produced 309 references of which 24 were reviews.

\section{Discussion}

Secondary malignancy of the penis as metastatic disease is a rare clinical entity, despite the rich vascularization of this organ even in flaccidity, with an increase in penile arterial blood flow to approximately 25 to 60 times that of the flaccid state during the rapid period of tumescence. Furthermore, at full rigidity, there is an entrapment of approximately $100 \mathrm{~mL}$ of blood which physiologically occurrs four to five times per night, lasting $30-45 \mathrm{~min}$. Therefore, there is a discrepancy between the relative blood supply and the rarity of the penis as site of secondary malignancy. According to the seed and soil hypothesis, and according to the fact that the site of metastasis is determined not only by the characteristics of the neoplastic cells but also by the microenvironment of the host tissue, the penis does not provide the perfect environment (soil) for neoplastic seeding. Furthermore, the rich communications between arterial inflow and venous outflow could explain the difficulty in cell seeding in normal conditions. However, when the outflow is impaired by venous or lymphatic occlusion, such as in the presence of tumor in the neighboring genito-urinary organs or in massive pelvic disease, the process of seeding could be facilitated.

Most metastatic lesions originate from the neighboring genito-urinary and pelvic organs, mainly bladder, prostate and rectum-sigmoid (28.6\%, $27.9 \%$ and $12.2 \%$, respectively). However, many primary sites have been described, including kidney, the hematologic system, lung, testis and other sites, totalling 504 reported cases to date (Table 1).
The earliest report of secondary penile malignancy was by Eberth in 1870. He reported a case of unusual metastasis from an adenocarcinoma of the rectum. ${ }^{4}$ In 1872, Roberts reported the first case of penile secondary malignancy as metastasis from a genitourinary tumor. ${ }^{5}$

The penis has a rich vascularization which increases during tumescence, and with respect to the arterial and venous systems it is an end organ. Despite this, the penis is a rare site of secondary malignancy. In 1956, Paquin hypothesized and described the possible mechanisms by which tumor cells spread to the penis. ${ }^{6}$ Generally speaking, we can only hypothesize the exact way in which they spread for each case and for each different primary tumor. In fact, penile secondary malignancy is usually associated with disseminated disease in which every metastastic mechanism could play a key role and each different primary tumor tends to metastatize according to different patterns. For example, a locally advanced rectal cancer, diffuse to the perineum with vein and lymphatic invasion, could metastatize to the penis by different routes.

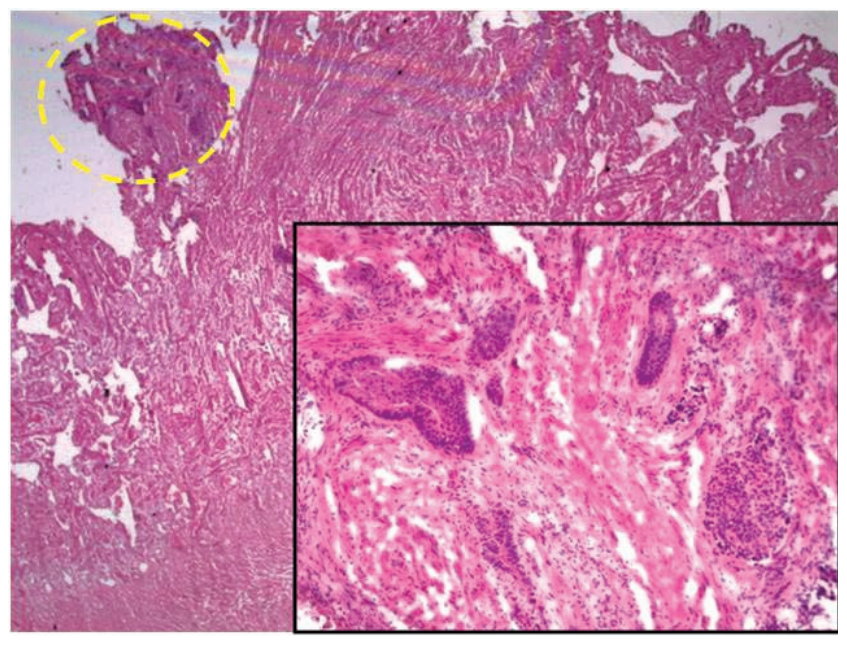

Figure 1. Frozen section of surgical margin (Original magnification 12.5X; insert 200X).
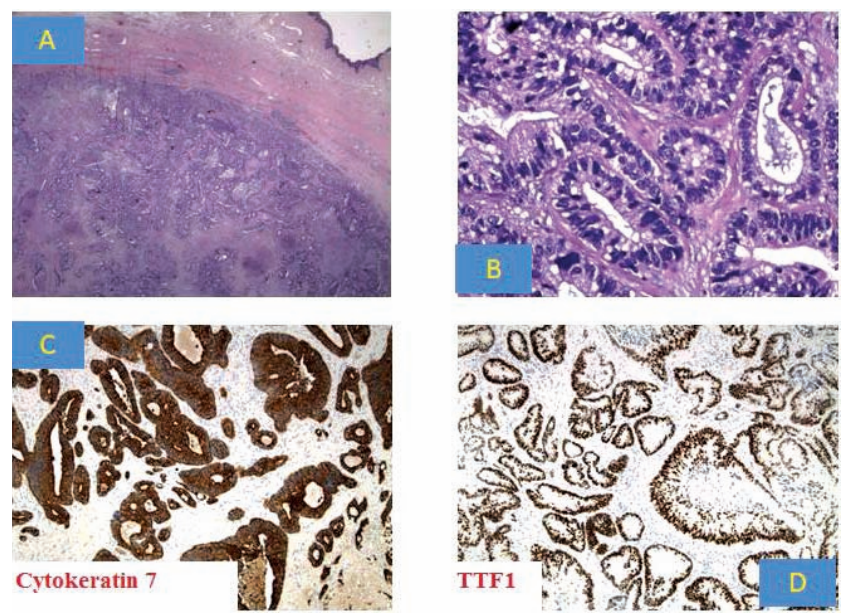

Figure 2. A) Microscopic view of the tumor; B) High-power view showing a proliferation made of gland structures; C) Intense and diffuse cytoplasmic staining for cytokeratin 7; D) Strong and diffuse nuclear staining for TTF1. (Original magnification: A) 12.5X; B) 400X; C) 200X; D) 100). 
The most accepted mechanisms of spread are: venous route, lymphatic system, the arterial spread, direct extension (continuity or contiguity) or by iatrogenic implantation.

The venous route, by retrograde flow, is the most common mechanism of spread to the penis. It is considered the major pathway of tumor spread to the penis because of: i) the higher incidence of penile secondary tumors from pelvic tumor by retrograde blood flow; ii) the low incidence of penile secondary malignancy despite the rich arterial inflow; iii) the low incidence of contemporary isolated ilio-inguinal lymph node enlargement in the most frequent causes of penile metastasis (i.e. tumor of pelvic organs), except for massive metastases. Anatomically, the blood coming from the cavernous spaces of the penis returns by a series of vessels which converge on the dorsum of the organ to form the deep dorsal vein. Some emerge from the under surface of the corpora cavernosa penis and receiving branches from the corpus cavernosum urethræ ending in the deep dorsal vein, while the largest number pass out at the root of the penis and join the prostatic plexus. The prostatic veins form a wellmarked prostatic plexus which communicates with the pudendal and vesical plexuses and with the vertebral vein and hemorrhoidal plexus. The established communication between the dorsal venous system of the penis and the venous plexuses draining the pelvic viscera provide routes for easy transportation of malignant cells from pelvic organs. This route of spread, through complex communication between penile veins and pelvic venous plexus, explains the higher incidence of secondary malignancy by pelvic tumor ${ }^{7}$ since most secondary tumors arise from the prostate, bladder and the recto-sigmoid. The existing connection between the prostatic plexus of Santorini and the deep dorsal vein of the penis are particularly important in prostate and bladder secondary tumors. The retrograde flow also explains the most common localization of the majority of secondary lesions which are located on the corpora cavernosa and the glans of the penis. A frequent contemporary pelvic lymph-node enlargement and compression causing a reversal of retrograde venous flow is sometimes involved, or the presence of an intermittent retrograde flow, for example due to an increase in intra-abdominal pressure.

In advanced recto-sigmoid cancer, there is evidence of extension within the hemorrhoidal veins as a special form of direct local extension. Veins may also be subjected to secondary invasion from neighboring lymphatic metastases.

The mechanism of spread through the retrograde lymphatic route is similar to the venous route. Invasion into the lymphatic system is followed by the transport of tumor cells to regional nodes and ultimately to other parts of the body. Anatomically, the skin of the penis and pre-

Table 1. List of primary tumours, with cases and incidence.

\begin{tabular}{lcc} 
Primary site & Total number & $\%$ \\
Bladder & 144 & 28.6 \\
Prostate & 141 & 27.9 \\
\hline Rectum-sigmoid & 61 & 12.2 \\
Kidney & 35 & 6.9 \\
\hline Lymphoma-others & 34 & 6.8 \\
Lung & 31 & 6.2 \\
\hline Lower gastrointestinal tract & 21 & 4.2 \\
Upper gastrointestinal tract & 11 & 2.2 \\
\hline Upper airways & 4 & 0.8 \\
Bone & 3 & 0.5 \\
\hline Ureter & 3 & 0.5 \\
Other organs & 16 & 3.1 \\
\hline Total & 504 & 100 \\
\hline
\end{tabular}

*Other organs included skin, upper gastrointestinal tract, seminal vesicle, stromal tissues, thyroid. puce is drained before the superficial inguinal nodes. The lymphatics of the glans may drain to the superficial inguinal nodes or feed directly to the deep inguinal nodes, while the lymphatics of the corporal bodies may drain to the superficial or deep inguinal nodes. Lymphatics from the lower rectum pass through the perineum into the inguinal nodes and then to the iliac nodes ${ }^{8,9}$ which are the common station of lymphatic drainage. These proximal connections permit tumor cells to spread along these vessels by permeation. This is the most common route of metastasis for carcinomas which spread along these vessels by retrograde permeation.

It is curious that the spread of tumors to the penis through the arterial route is rare, as also are sarcomatous secondary tumors in the penis which usually disseminate through the arterial route. The arterial supply to the penis originates from the right and left internal pudendal arteries which, in turn, arise from the anterior division of the internal iliac arteries and give rise to the common penile arteries. The branches of the common penile artery are: the bulbourethral artery, the dorsal artery of the penis and the cavernosal artery. The bulbourethral artery supplies the penile bulb, the bulbourethral (Cowper) glands, and the posterior aspect of the corpus spongiosum, and it gives rise to the urethral artery. The paired deep dorsal arteries lie external to the tunica albuginea, supplying the penile skin and the glans penis. The deep branch of the penile artery or cavernosal artery enters the cavernous body of the penis and provides the helicine arteries that fill the sinusoidal space. Tumor cells reach, permeate and spread through the arterial circulation by direct tumor extension into the arterial pathways (e.g. invading branches of aorta, common iliac, hypogastric or pudendal artery) or metastatic tumor emboli (usually originating from secondary deposits in the lung or other organs which produce metastasis to the lung).

Tumor spread by continuity or contiguity is possible from some closer primary tumors (i.e. prostate, bladder, recto-sigmoid) which lie close to the organ. In this case, the metastastic deposit is presumed to be a lesion involving the proximal parts of the penile shaft. This is, strangely, extremely rare.

Tumor spread due to implantation and secondary to instrumentation ${ }^{10}$ involves mechanical seeding of tumor cells by surgical instruments. These have been described as possible mechanisms for tumor spread to the penis. This is, however, highly unlikely since isolated lesions of the corpus spongiosum (which surrounds the urethra) without concomitant involvement of other structures, such as the corpora cavernosa or the glans, are extremely rare.

To date, over 500 cases of secondary penile malignancy have been reported.

As primary tumors, bladder cancer, ${ }^{11-45}$ prostate carcinoma ${ }^{46-90}$ and recto-sigmoid cancer ${ }^{91-117}$ as pelvic malignancy represent about $69 \%$ of all cases, followed by renal carcinoma in $6.9 \%,{ }^{118-131}$ hematologic disease, ${ }^{132,133}$ and involvement of lung ${ }^{134-159}$ and other organs. ${ }^{160-180}$

The higher incidence of primary malignancy in the pelvic organs means the most common route of tumor spread is through veins and lymphatics and by direct extension; a spread of the tumor in and along prostatic nerves has also been documented. ${ }^{41}$ Other primary malignancies, such as lung or kidney cancer, or hematologic disease, usually spread through the arterial route.

These lesions, when synchronous, are often associated with disseminated malignancy and have, therefore, a poor outcome. Sometimes there is metachronous metastatic involvement of the penis only years after the primary tumor has been diagnosed, staged, treated and apparently cured, without evidence of any other metastatic lesions. Most rare is penile involvement as first manifestation of tumor, such as in our case. This seems to be slightly more frequent, at least according to an analysis of the literature, in malignancies secondary to lung cancer.

The mean age of presentation in most cases represents the common age-related incidence of primary malignancy, usually $60-80$ years considering the most common primaries, i.e. bladder, prostate and rectal 
cancer. This represents the common disease-related time between the discovery of primary tumor and the development of metastasis.

About $60 \%$ of patients with penile metastasis present with symptoms related to the presence of nodules which in $70 \%$ of cases involves both corpora cavernosa. Metastasis is unilateral in only $15 \%$ of cases, whereas the corpus spongiosum and glans penis (with skin ulcerative lesions) $)^{71}$ are each involved in $10 \%$ of patients and the prepuce in approximately 5\%.27,92,99 Exclusive skin lesions are extremely rare according to the most frequent route of dissemination. The high incidence of bilateral involvement is due to the fact that the corpora cavernosa communicate freely through an incomplete midline septum. Mass or induration of the penis is the most common presentation for bladder (89\% of cases), prostate (96\%) and recto-sigmoid (95\%) cancers which usually are solid adenocarcinoma.

Priapism, the so-called malignant priapism, ${ }^{11,16,20,24,34,44,46,111,123,150}$ is reported with varying frequencies of from 20 to $53 \%$. It is usually associated with a mass or induration of the penis. It is a prominent feature in most patients with hematologic secondary malignancy ${ }^{133}$ or in patients with vein invasion and thrombosis, and it mimics a low flow malignant priapism. It is caused by occlusion of the draining veins and/or is secondary to thrombosis in the cavernosal spaces caused by diffusion and invasion by tumor cells, or by irritation of the neural pathways caused by the metastatic tumor. Most rarely, arterial rupture or fistulae due to tumor invasion may result in secondary high-flow priapism. ${ }^{33}$

The other common clinical presentations of penile metastasis are problems in voiding, and penile or perineal pain.

Pain is not an initial symptom in most patients but becomes prominent in advanced disease; pain is partly experienced in the penis and partly in the crura or perineum. It is frequent in cases of malignant priapism or massive infiltration of corpora cavernosa.

Symptoms related to obstructive voiding ${ }^{84}$ and hematuria are very rarely reported ${ }^{38,120}$ since urethral secondary malignancy is rare. However, in locally advanced disease, urethral compression and/or invasion are frequent.

Penile metastasis must be differentiated from some pre-malignant and malignant primitive lesions (such as Bowen's disease, erythroplasia of Queyrat, verrucous carcinoma, squamous cell carcinoma, melanoma and sarcoma), some infective diseases (tubecolosis, chancroid, syphiloma), and other most common benign conditions, mainly Peyronie's disease or non-malignant priapism. According to all reported cases, penile secondary malignancy is rarely a skin disease, such as primitive penile cancer or infective diseases, and the appearance of a deep nodule or priapism in older patients with a previous history of cancer must be investigated.

Diagnosis is usually made by biopsy ${ }^{15,34}$ or fine-needle aspiration ${ }^{181}$ which helps to differentiate between metastasis ${ }^{182}$ and primary tumors. Some secondary malignanciees are variants of common primary tumor hystotypes. For example, prostate cancer usually has primary tumors that are compatible with a diagnosis of ductal adenocarcinoma which is a distinct subtype of prostate carcinoma that commonly involves the prostatic urethra. ${ }^{59}$ Immunohystochemistry ${ }^{59,97,98}$ is an excellent technique for typing tumors by the most common histological marker, such as carcino-embryogenic antigen to identify adenocarcinoma, cytokeratins to identify carcinomas (but also expressed in some sarcomas), PSA for prostate cancer, ${ }^{59}$ and some cluster of differentiation for renal cell carcinoma, hematologic disease and lymphoma.

Non-invasive modalities, such as ultrasound scan, ${ }^{183,184}$ colordoppler ultrasonography (helpful for differentiating between high- and low-flow priapism), computerized tomography (CT) and MRI are being increasingly used to diagnose and stage the disease, while invasive cavernosography has been abandoned. ${ }^{185,186}$ However, ultrasonography is operator dependant, whereas the imaging of CT in only one plane limits the diagnostic value of the test. MRI scanning is a reliable alternative for confirming the diagnosis and assessing in detail the exten- sion of the disease. ${ }^{187,188}$ On T1-weighted images, these lesions usually have low signal intensity, similar to the surrounding corpus cavernosum. 0n T2-weighted imaging, they appear non-homogenous with low to intermediate signal intensity seen clearly against the high background intensity of the cavernosal bodies.

Metastatic cancer may be treated with systemic therapy (chemotherapy, biological therapy, targeted therapy, hormonal therapy) local therapy (surgery, radiation therapy), or a combination of these treatments. ${ }^{31}$ The choice of treatment generally depends on the type (histology) of the primary cancer, the size, location, and number of metastatic tumors, patient age and general health, and the type of any previous treatment. Even in cases of penile secondary, the choice of treatment is greatly influenced by the general health of the patient, as well as the site of the primary tumpr, the extent of metastatic spread, and the severity of systemic and local symptoms. Most older patients will require only supportive or palliative therapy.

Local excision, partial or complete penectomy, ${ }^{41,151,189}$ external beam radiotherapy, ${ }^{102}$ brachytherapy ${ }^{67}$ and chemotherapy ${ }^{39}$ have all yielded poor local results. Standard treatment of priapism is usually ineffective. ${ }^{46}$

Except for a few patients with small isolated lesions which might respond to a wide excision or penectomy, most succumb to the disease process within a year of presentation. For intractable pain, total penectomy or dorsal nerve section may be indicated, while in cases of urethral stenosis, a temporary urinary diversion (i.e. supra-pubic catheter ${ }^{57}$ ) is sufficient. For pallation purposes, the potential benefit of combining radiotherapy and chemosensitizer can only be speculated because of the scarcity of data and clinical experience. Oxygen is a potent radiosensitizer and increases the effectiveness of radiation by forming DNA-damaging free radicals. However, the flaccid penis has a hypoxic cavernosal state which increases in the presence of priapism, and both conditions are typical of penile secondary malignancies. Other radiosensitizing agents, such as cisplatin, 5-fluorouracil, 5-iodo2'-deoxyuridine, gemcitabine, capecitabine, fludarabine, or imatinib are currently in common clinical use to improve radiation therapy. However, there are few experiences of penile secondary malignancies.

In general, the outcome of patients presenting with secondary malignancy in the penis is very poor. Most patients have widespread metastatic disease. They are in poor general health and will die within six months of presentation, irrespective of the primary tumor and treatment, making palliative non-invasive treatment advisable. Overall, patients with prostate tumor seem to fare slightly better, with survival reported of over nine years. ${ }^{190}$ Patients with genitourinary primary (bladder) had an average survival of only 47 weeks, even with aggressive treatment.

\section{Conclusions}

Secondary malignancy of the penis is uncommon and clinical evidence of penile involvement in a patient with a history of malignancy is an ominous sign and should alert the clinician to a dismal prognosis.

The rarity of these lesions, the variety of clinical presentation and the overall poor outcome make planning a well-balanced and appropriate treatment after histological diagnosis extremly problematic. This review has also emphasized that in patients with a known primary malignancy, even if cured, the development of penile mass, painful priapism, and lower urinary tract symptoms indicate that, although rare, metastases to the penis should be considered in differential diagnosis and correctly addressed. Most penile secondary malignancies come from prostate, bladder or the recto-sigmoid, and are usually associated with disseminated metastatic disease. Diffusion to the penis is usually by the retrograde venous route, followed by lymphatic and direct invasion.

In the case presented here, penile tumor represented the first clini- 
cal manifestation of unknown metastatic lung cancer. This patient had adenocarcinoma of the lung that metastasized to the penis; this has only been reported twice. ${ }^{135,150}$ Arterial spread may be a more plausible explanation for the metastasis from lung cancer, only occurring in the deep corpora cavernosa without involvement of the skin or prepuce, mimicking a diffuse and painful Peyronie's disease.

The overall outcome is very poor and most patients will require only palliative or supportive care. However, in cases of local untractable pain or urethral stricture, partial amputation with urethral clearing will at least improve the quality of life to these patients who have very limited prospects of survival.

\section{References}

1. Parkin DM, Bray F. The burden of HPV-related cancers. Vaccine 2006;24 Suppl 3:S3/11-25.

2. Parkin DM. Cancer incidence in five continents. Lyon, France: International Agency for Research on Cancer (IARC Publications); 2002.

3. Horner MJ, Ries LAG, Krapcho M, et al. SEER cancer statistics review, 1975-2006. Bethesda, MD: National Cancer Institute; 2009. Available from: http://seer.cancer.gov/csr/1975_2006/index.html

4. Eberth CJ. Krehsmetastasen des corpus cavernosum penis. Virch Arch 1870;51:145.

5. Roberts W. A practical treatise on urinary and renal disease. 2nd edition. London: Smith, Elder \& Co; 1872. pp. 517.

6. Paquin AJ Jr, Roland SI. Secondary carcinoma of the penis. A review of the literature and a report of nine new cases. Cancer 1956;9:626.

7. Abeshouse BS, Abeshouse GA. Metastatic tumors of the penis: a review of the literature and a report of two cases. J Urol 1961;86:99-112.

8. Paño B, Sebastià C, Buñesch L, et al. Pathways of lymphatic spread in male urogenital pelvic malignancies. Radiographics 2011;31:135-60.

9. McMahon CJ, Rofsky NM, Pedrosa I. Lymphatic metastases from pelvic tumors: anatomic classification, characterization, and staging. Radiology 2010;254:31-46.

10. Turner AG. Pagetoid lesions associated with carcinoma of the bladder. J Urol 1980;123:124-6.

11. Ellanti P, Connolly SS, McDermott R, et al. Malignant priapism: a case report. Ir J Med Sci 2011;180:921-2.

12. Chaux A, Amin M, Cubilla AL, Young RH. Metastatic tumors to the penis: a report of 17 cases and review of the literature. Int J Surg Pathol 2011;19:597-606.

13. Sönmez NC, Co kun B, Arisan S, et al. Early penile metastasis from primary bladder cancer as the first systemic manifestation: a case report. Cases J 2009;14:7281.

14. Hadzi-Djoki J, Pejci T, A imovi M, et al. Penile metastasis from invasive bladder cancer. Acta Chir lugosl 2009;56:101-3.

15. Santos Gda C, de Alvarenga ML, Borlot VF, et al. Penile metastasis of urothelial carcinoma diagnosed by fine-needle aspiration. Cytojournal 2009;6:10.

16. Celma Doménech A, Planas Morin J, de Torres Ramírez I, et al. Priapism secondary to penis infiltration of bladder cancer. Actas Urol Esp 2008;32:749-51.

17. Sari A, Uyaroglu MA, Ermete M, et al. Microcystic urothelial carcinoma of the urinary bladder metastatic to the penis. Pathol Oncol Res 2007;13:170-3.

18. Hizli F, Berkmen F. Penile metastasis from other malignancies. A study of ten cases and review of the literature. Urol Int 2006;76: $118-21$.
19. Bordeau KP, Lynch DF. Transitional cell carcinoma of the bladder metastatic to the penis. Urology 2004;63:981-3.

20. Trívez Boned MA, Aranda Lassa JM, Lozano Enguita J, et al. Transitional carcinoma and malignant priapism. Actas Urol Esp 2004;28:694-7.

21. Guvel S, Kilinc F, Torun D, et al. Malignant priapism secondary to bladder cancer. J Androl 2003;24:499-500.

22. Berger AP, Rogatsch H, Hoeltl L, et al. Late penile metastasis from primary bladder carcinoma. Urology 2003;62:145.

23. Gentile V, Mariotti G, Fattore F, et al. Penile metastasis from bladder cancer. A case report. Minerva Urol Nefrol 2002;54:129-30.

24. Casoli E, Di Fiore F, Longobardi S, et al. Metastatic penile lesions secondary to transitional cell carcinoma of the bladder: a rare cause of "malignant priapism". Arch Ital Urol Androl 2002;74:48-9.

25. Khan MA, Tao W, Mathews P, Potluri BS. Penile metastasis arising from transitional cell carcinoma of the urinary bladder. Urol Int 2001;66:162-3.

26. Wolfensberger UE, Bagot A, Hailemariam S, et al. Penile metastasis of carcinoma of the urinary bladder. Praxis (Bern 1994) 2001; 90:69-71

27. Miyamoto T, Ikehara A, Araki M, et al. Cutaneous metastatic carcinoma of the penis: suspected metastasis implantation from a bladder tumor. J Urol 2000;163:1519.

28. Buzzi G, D’Avanzo M, D'Aprile MR, Lanciotti S. A case of metastasis to the corpora cavernosa from a bladder carcinoma. Radiol Med 2000;99:202-3.

29. Horinaga M, Kosugi M, Ikeuchi K. A case of urothelial carcinoma associated with penile metastasis. Hinyokika Kiyo 1999;45:713-5.

30. Demuren 0A, Koriech 0. Isolated penile metastasis from bladder carcinoma. Eur Radiol 1999;9:1596-8.

31. Kitsukawa S, Kinn T, Yoshida T, et al. Successful multidisciplinary treatment for bladder cancer with priapism. A case report. Nihon Hinyokika Gakkai Zasshi 1998;89:788-91.

32. Guo M, Lemos LB, Baliga M, Fowler JE Jr. Fine needle aspiration biopsy of the penis: transitional cell carcinoma of the urinary bladder with mucinous differentiation. Urology 1998;51:1040-2.

33. Dubocq FM, Tefilli MV, Grignon DJ, et al. High flow malignant priapism with isolated metastasis to the corpora cavernosa. Urology 1998;51:324-6.

34. Chan PT, Bégin LR, Arnold D, et al. Priapism secondary to penile metastasis: a report of two cases and a review of the literature. J Surg Oncol 1998;68:51-9.

35. Allen RA, Bumpers HL, Kennedy AP, et al. Primary adenocarcinoma, signet-ring, and transitional cell carcinoma of the bladder with penile metastasis. J Natl Med Assoc 1997;89:253-6.

36. Maier U, Grimm M. Transitional cell carcinoma of the bladder with solitary metastasis to the penis 4 years after successful heart transplantation. A case report and review of the literature. Transplantation 1994;58:861-3.

37. Ucar FJ, Robles JE, Isa WA, et al. Secondary carcinoma of the penis. A report of three new cases. Eur Urol 1989;16:308-9.

38. Takahashi S, Ozono S, Cho M, et al. Penile and urethral metastases from superficial bladder tumor after TUR: a case report. Hinyokika Kiyo 1989;35:1055-9.

39. Matthewman PJ, Oliver RT, Woodhouse CR, Tiptaft RC. The role of chemotherapy in the treatment of penile metastases from carcinoma of the bladder. Eur Urol 1987;13:310-2.

40. Haddad FS, Kivirand AI. Metastases to the corpora cavernosa from transitional cell carcinoma of the bladder. J Surg Oncol 1986;32:1921.

41. Haddad FS. Penile metastases secondary to bladder cancer. Review of the literature. Urol Int 1984;39:125-42.

42. Tuttle JP Jr, Rous SN, Kinzel RC. Bladder epithelial neoplasms metastatic to glans penis. Urology 1976;8:80-1. 
43. Aboulker P, Berge D, Roujeau J. 3 cases or penal metastasis in bladder cancer. J Urol Medicale Chir 1960;66:555-61.

44. Berard LN, Byrne JE. Priapism due to unusual metastasis from bladder carcinoma: case report. J Urol 1953;70:261-6.

45. Fort CA, Bailey MK, Kicklighter JE. Primary carcinoma of bladder with secondary metastasis to penis. J Urol 1951;66:238-41.

46. Lin YH, Kim JJ, Stein NB, Khera M. Malignant priapism secondary to metastatic prostate cancer: a case report and review of literature. Rev Urol 2011;13:90-4.

47. Yildiz B, Fidan E, Yildiz K, Aydin F. Penile metastasis from adenocarcinomaof the prostate in a patient with colorectal carcinoma. Acta Dermatovenerol Croat 2011;19:36-8.

48. Kobashi-Katoh R, Tanioka M, Takahashi K, Miyachi Y. Skin metastasis of prostate adenocarcinoma to glans penis showing no correlation with serum prostate-specific antigen level. J Dermatol 2009;36:106-8.

49. Rohan V, Hanji A, Patel J, et al. Penile metastases from prostate cancer. Urol J 2009;6:217-9.

50. Uphoff J, Woziwodzki J, Schattka SO, Kollias A. Loss of differentiation of a prostate adenocarcinoma after hormone therapy: the example of a metastasis in the spongy body of the penis. Aktuelle Urol 2008;39:373-7.

51. Wang SQ, Mecca PS, Myskowski PL, Slovin SF. Scrotal and penile papules and plaques as the initial manifestation of a cutaneous metastasis of adenocarcinoma of the prostate: case report and review of the literature. J Cutan Pathol 2008;35:681-4.

52. Cai T, Salvadori A, Nesi G, et al. Penile metastasis from a T1b prostate carcinoma. Onkologie 2007;30:249-52.

53. Cortés González JR, Garza R, Martínez R, Gómez L. Prostate adenocarcinoma metastatic to penis. Actas Urol Esp 2006;30:832-4.

54. Sawada A, Segawa T, Nakanishi S, et al. Prostate cancer with penile metastasis: a case report. Hinyokika Kiyo 2005;51:771-3.

55. Sanz Mayayo E, Burgos Revilla FJ, Gómez García I, et al. Penile metastasis of a prostatic adenocarcinoma. Arch Esp Urol 2004;57: 841-4.

56. Ansari H, Prashant R, Franks A. Prostatic carcinoma metastasis to the penis--an uncommon site. Lancet Oncol 2003;4:705-6.

57. Philip J, Mathew J. Penile metastasis of prostatic adenocarcinoma: Report of two cases and review of literature. World J Surg Oncol 2003;1:16.

58. Senkul T, Karademir K, Silit E, et al. Penile metastasis of prostatic adenocarcinoma. Int J Urol 2002;9:597-8.

59. Tu SM, Reyes A, Maa A, et al. Prostate carcinoma with testicular or penile metastases. Clinical, pathologic, and immunohistochemical features. Cancer 2002;94:2610-7.

60. Schellhammer F, Nazari S, Krug B. Penis metastasis of prostate carcinoma. Rofo 2002;174:904.

61. Geetha G, Nagarajan V, Tulasi NR, Nagarajan M. Carcinoma prostate with penile metastases. A case report. Indian J Cancer 2002;39:73-4.

62. Kotake Y, Gohji K, Suzuki T, et al. Metastases to the penis from carcinoma of the prostate. Int J Urol 2001;8:83-6.

63. Sciarra A, D’Eramo G, Casale P, et al. Penile metastasis from carcinoma of the prostate in a patient with high serum prostate specific antigen levels. Minerva Urol Nefrol 1999;51:157-8.

64. Ortiz Cabria R, Adriazola Semino M, Blanco Parra MA, et al. Skin lesions of the penis. Prostatic adenocarcinoma metastasis. Report of a case. Actas Urol Esp 1999;23:153-5.

65. Pandian SS, McGuire M, McClinton S, Kerr KM. Penile metastases from carcinoma of the prostate. Br J Urol 1997;79:807.

66. Char G, Douglas LL, Sawh D. Metastatic carcinoma of the penis. West Indian Med J 1996;45:37-8.

67. Griffin JH, Wheeler JS Jr, Olson M, Melian E. Prostate carcinoma metastatic to the penis: magnetic resonance imaging and brachytherapy. J Urol 1996;155:1701-2.

68. Buchholz NP, Moch H, Feichter GE, et al. Clinical and pathological features of highly malignant prostatic carcinomas with metastases to the penis. Urol Int 1994;53:135-8.

69. Marchal Escalona C, Contreras Martínez J, Chicharro Molero JA, et al. Metastatic disease of the penis. Report of 3 cases. Actas Urol Esp 1993;17:461-3.

70. Osther PJ, Løntoft E. Metastasis to the penis. Case reports and review of the literature. Int Urol Nephrol 1991;23:161-7.

71. Romero Pérez P, Amat Cecilia M, Andrada Becerra E. Metastasis in the glans of prostatic adenocarcinoma. Apropos of a case. Actas Urol Esp 1991;15:284-7.

72. López de Alda A, Rodríguez Miñón Cifuentes JL, García de la Peña E, et al. Penile metastasis of prostatic carcinoma. Apropos of a case. Actas Urol Esp 1990;14:163-4.

73. Iturregui-Pagán JR, Trujillo 0. Prostatic cancer with metastasis to the penis. Bol Asoc Med P R 1989;81:223-4.

74. Fiorelli RL, Finkelstein LH, Fernandes JJ. Metastasis of prostate gland adenocarcinoma to penile and scrotal cutaneous tissues. J Am Osteopath Assoc 1989;89:349-52.

75. Holubár J, Petr J, Foukal T. Report of a rare metastasis of prostatic adenocarcinoma to the penis. Rozhl Chir 1987;66:741-5.

76. Berbis P, Andrac L, Daou N, Privat Y. Single nodule on the glans penis: metastatic lesion from an unusual carcinoma of the prostate. Dermatologica 1987;175:152-5.

77. Savion M, Livne PM, Mor C, Servadio C. Mixed carcinoma of the prostate with penile metastases and priapism. Eur Urol 1987;13: $351-2$.

78. van den Berg GM, Menke HE, Stolz E. Nodules on the glans penis, an unusual metastatic pattern of prostate carcinoma: case report. Genitourin Med 1986;62:126-8.

79. Haddad FS, Manne RK. Prostatic tumors with penile secondaries. Review of the literature with a case report. Urol Int 1986;41:465-70.

80. Powell FC, Venencie PY, Winkelmann RK. Metastatic prostate carcinoma manifesting as penile nodules. Arch Dermatol 1984;120: 1604-6.

81. Jepsen JM, Pedersen JK, Andersen J. Cancer of the prostate with metastasis to the penis. Ugeskr Laeger 1981;143:2236-7.

82. Smehaug J. Metastases to the penis from carcinoma of the prostate. A case report. Scand J Urol Nephrol 1979;13:205-6.

83. Patel NP, Ward JN. Carcinoma of prostate metastatic to prepuce and glans penis. Urology 1978;11:269-70.

84. Spreen SA, Keys RH Jr, Evans AT. Acute urinary retention secondary to metastatic prostatic carcinoma to the penis: a case report. J Urol 1975;113:59.

85. Thivolet J, Molinie C, Moulin G, Proust J. [Metastases of the penis during prostatic cancer. (Apropos of a case of isolated cutaneous metastasis of the gland)]. Dermatologica 1965;130:221-30. [Article in French].

86. Garofalo F. On a case of metastasis to the corpora cavernosa of the penis of carcinoma of the prostate. Arch Ital Urol 1963;36:138-48.

87. Laska A. A case of metastasis of prostatic cancer in the penis. Pol Przegl Chir 1963;35:399-401.

88. Corrado F. Metastasis of prostate neoplasms to the corpora cavernosa of the penis. Minerva Urol 1957;9:152-5.

89. Bernardi R, Tinelli J. [Cancer of the prostate and cancer of the cavernous bodies; metastasis?] Rev Argent Urol 1955;24:266-8. [Article in Spanish].

90. Waller JI, Hellwig CA. Metastasis to the corpora cavernosa from carcinoma of the prostate. J Urol 1953;69:157-63.

91. Maestro MA, Martínez-Piñeiro L, Moreno SS, et al. Penile metastasis of rectal carcinoma. Case report and bibliographic review. Arch Esp Urol 2011;64:981-4.

92. Gbenou MC, Wahidy T, Llinares K, et al. Atypical phimosis second- 
ary to a preputial metastasis from rectal carcinoma. Case Rep Oncol 2011;4:542-6.

93. Küronya Z, Bodrogi I, Lövey J, et al. Metachronous metastasis from rectal adenocarcinoma to the penis--case report. Magy Onkol 2009;53:263-6.

94. Park JC, Lee WH, Kang MK, Park SY. Priapism secondary to penile metastasis of rectal cancer. World J Gastroenterol 2009;15:4209-11.

95. Ozawa H, Muramoto M, Watanabe M. Metastasis to the penis from cecum carcinoma. Int J Urol 2009;16:770.

96. Chung TS, Chang HJ, Kim DY, et al. Synchronous penile metastasis from a rectal carcinoma. Int $\mathrm{J}$ Colorectal Dis 2008;23:333-4.

97. Murhekar KM, Majhi U, Mahajan V, Satheesan B. Penile metastasis from rectal carcinoma. Indian J Cancer 2007;44:155-6.

98. Ketata S, Boulaire JL, Soulimane B, Bargain A. Metachronous metastasis to the penis from a rectal adenocarcinoma. Clin Colorectal Cancer 2007;6:657-9.

99. Añibarro Laca E, Pérez-Irezabal Pindado JC, Ibáñez Calle T, Llarena Ibarguren R. Metastases from a rectal adenocarcinoma to the prepuce. Arch Esp Urol 2006;59:737-9.

100. Cherian J, Rajan S, Thwaini A, et al. Secondary penile tumours revisited. Int Semin Surg Oncol 2006;3:33.

101. Pellicé i Vilalta C. Subcutaneous prepuce metastasis secondary to rectal adenocarcinoma. Arch Esp Urol 2006;59:926.

102. Appu S, Lawrentschuk N, Russell JM, Bright NF. Metachronous metastasis to the penis from carcinoma of the rectum. Int $\mathrm{J}$ Urol 2006;13:659-61.

103. Banerjee GK, Lim KP, Cohen NP. Penile metastasis: an unusual presentation of metastatic colonic cancer. J R Coll Surg Edinb 2002;47:763-4.

104. Tan BK, Nyam DC, Ho YH. Carcinoma of the rectum with a single penile metastasis. Singapore Med J 2002;43:39-40.

105. Sukumar N, Qureshi A. Adenocarcinoma of rectum metastasizing to penis. Med J Malaysia 2001;56:255-6.

106. Al-Mashat F, Sibiany A, Rakha S, Olumide F. Penile metastasis from rectal carcinoma. Saudi Med J 2000;21:379-81.

107. Lange G, Fagot H, Faulques B, et al. Penile metastasis of recto-sigmoid adenocarcinoma. Apropos of a case. Ann Chir 1997;51:294-6.

108. Comandone A, Bau G, Mo A, et al. Metastasis to the penis from carcinoma of the rectum. A clinical case. Minerva Gastroenterol Dietol 1992;38:49-52.

109. Haddad FS, Manne RK. Involvement of the penis by rectocolic adenocarcinoma. Report of a case and review of the literature. Dis Colon Rectum 1987;30:123-9.

110. Khubchandani M. Metachronous metastasis to the penis from carcinoma of the rectum. Report of a case. Dis Colon Rectum 1986;29:52-4.

111. Okumura S, Hirasawa S, Yui Y, et al. A clinical case of secondary tumor of the penis from the rectum, with malignant priapism. Hinyokika Kiyo 1984;30:205-15.

112. Zanetti PP, Calabrò B, Gagna G, et al. Metastasis to the corpus cavernosum of the penis from a rectal cancer. Minerva Urol 1983;35: 69-71.

113. Rees BI. Secondary involvement of the penis by rectal cancer. Br J Surg 1975;62:77-9.

114. Tagart RE. Secondary deposit of rectal carcinoma in the penis. Proc R Soc Med 1967;60:501.

115. Oehlschlaegel G. The corpora cavernosa penis as a site for secondary tumor seeding in cancer of the rectum. Z Haut Geschlechtskr 1966;41:425-9.

116. McCrea LE, Bacon HE. Metastasis to the penis from carcinoma of the bowel. Dis Colon Rectum 1958;1:376-80.

117. Cattell RB, Mace AJ. Metastasis to the penis from carcinoma of the rectum. J Am Med Assoc 1951;146:1230-1.

118. Romero Selas E, Lamas Meilán C, Barbagelata López A, et al.
Metastasis of a renal cell carcinoma in the corpora cavernosum of the penis. Case report and bibliographic review. Arch Esp Urol 2006; 59:530-2.

119. Pérez Fentes DA, Blanco Parra M, Toucedo Caamaño V, et al. Atypical sites of metastatic renal carcinoma. Literature review. Actas Urol Esp 2005;29:621-30.

120. Pascual Mateo C, Nieto Gallo MA, Luján Galán M, et al. Acute urinary retention and hematuria secondary to metastatic renal clearcell carcinoma to the penis. Actas Urol Esp 2005;29:593-5.

121. Herrera Puerto J, Herrera Flores J, López Elzaurdia C, et al. Penile metastasis of renal cell carcinoma. Actas Urol Esp 2002;26:589-91.

122. Takahashi H, Hirano Y, Ishikawa A, et al. Penile metastasis from renal cell carcinoma: a case report. Hinyokika Kiyo 2000;46:463-5.

123. Nezu FM, Dhir R, Logan TF, et al. Malignant priapism as the initial clinical manifestation of metastatic renal cell carcinoma with invasion of both corpora cavernosum and spongiosum. Int J Impot Res 1998;10:101.

124. Fallick ML, Long JP, Ucci A. Metachronous renal cell carcinoma metastases to spermatic cord and penis. Scand J Urol Nephrol 1997;31:299-300.

125. Puppo P, Perachino M, Ricciotti G, Vitali A. Malignant priapism due to a huge renal carcinoma. Eur Urol 1992;21:169-71.

126. Daniels GF Jr, Schaeffer AJ. Renal cell carcinoma involving penis and testis: unusual initial presentations of metastatic disease. Urology 1991;37:369-73.

127. Adjiman S, Flam TA, Zerbib M, et al. Delayed nonurothelial metastatic lesions to the penis: a report of two cases. Eur Urol 1989;16:391-2.

128. Sarma DP, Woods AL 3rd, Rodriguez FH Jr, et al. Priapism as the presenting feature of renal cell carcinoma. J Surg Oncol 1985;28: 103-7.

129. Ali Khan S, Desai PG, Jayachandran S, Smith N. Metastases to the penis from renal cell carcinoma. Int Urol Nephrol 1984;16:323-5.

130. Katz SA, Davis JE. Hypernephroma presenting as solitary metastasis to penis. Urology 1976;7:206-9.

131. Bachrach P, Dahlen CP. Metastatic tumors to the penis. Urology 1973;1:359-62.

132. Gallardo F, Pujol RM, Barranco C, Salar A. Progressive painless swelling of glans penis: uncommon clinical manifestation of systemic non-Hodgkin's lymphoma. Urology 2009;73:929.

133. Vadakan VV, Ortega J. Priapism in acute lymphoblastic leukemia. Cancer 1972;30:373-5.

134. Haliloglu AH, Haliloglu N, Akpinar EE, Ataoglu 0. Erectile dysfunction: initial symptom of a patient with lung cancer. J Sex Med 2011;8:3511-4.

135. Zheng FF, Zhang ZY, Dai YP, et al. Metastasis to the penis in a patient with adenocarcinoma of lung, case report and literature review. Med Oncol 2009;26:228-32.

136. Sofikerim M, Gülmez I, Tokat F, et al. Epidermoid carcinoma of the lung with isolated penile metastasis. Can J Urol 2007;14:3643-5.

137. Rong L. A case of squamous cell carcinoma of the lung with metastasis to adrenal gland and the penis was treated by Gefitinib. Linchuang Zhongliuxue Zazhi 2006;11:639.

138. Fujimoto N, Hiraki A, Ueoka H, Harada M. Metastasis to the penis in a patient with squamous cell carcinoma of the lung with a review of reported cases. Lung Cancer 2001;34:149-52.

139. Fischer MA, Patrick A. Secondary penile carcinoma from squamous cell carcinoma of the lung. Can J Urol 1999;6:899-900.

140. Ortiz de Saracho J, Castrodeza Sanz R, Guzmán Dávila G. Penile metastasis and pulmonary carcinoma. Arch Bronconeumol 1998;34:226-7.

141. Danno S, Okada H, Mikami O, et al. Metastatic tumor to the penis from lung cancer: report of two cases. Acta Urol Jpn 1997;43:61-3.

142. Bonaminio A, Shingleton WB. Squamous cell carcinoma of the 
lung with metastasis to the penis. South Med J 1995;88:761-2.

143. Dong W. A case of squamous cell carcinoma of the lung with metastasis to the penis. Zhonghua Miniao Waike Zazhi 1995;16:320.

144. Lorente FJ, Scavuzzo H. Metastasis to the penis of pulmonary epidermoid carcinoma. Actas Urol Esp 1994;18:231-3.

145. Yokoi K, Miyazawa N, Muraki J, et al. Penile metastasis from lung cancer. Jpn J Clin Oncol 1992;22:297-9.

146. Pálfi Z, Zana J, Világosi C, Pödör P. Carcinoma of the penis as a metastasis. Acta Chir Hung 1988;29:323-6.

147. Ortiz Cansado A, García Alonso P, Escobar Alvarez Y, López de Juan M. Metastasis in the corpus cavernosum of the penis as primary manifestation of epidermoid carcinoma of the lung. Med Clin (Barc) 1988;91:159.

148. Takenawa J, Sasaki M, Ueno Y, Akiyama F. Metastatic penile tumor from lung cancer: a case report. Acta Urol Jpn 1987;33:1281-4.

149. Schwesinger G, Braune T. Penismetastasen eines Bronchuskarzinoms. Z Urol Nephrol 1986;79:499-502.

150. Usui A, Nakamoto T, Ishino T, Fukushige M. Metastatic carcinoma of the penis with malignant priapism: two case reports. Nishi Nippon Hinyokika 1985;47:843-6.

151. Honda M, Kameoka H, Miyoshi S, et al. Secondary penile tumors: report of two cases. Hinyokika Kiyo 1985;31:2273-9.

152. Van Wyk CE. Bronchogenic carcinoma metastasizing to the heart and penis. A case report. S Afr Med J 1983;64:255-6.

153. Silber I. Penile metastases from bronchogenic carcinoma. Urology 1976;7:536-7.

154. Pikula B, Nikulin A, Plamenac P, Ljubovi E. Metastasis of bronchogenic carcinoma in the penis. Lijec Vjesn 1972;94:345-8.

155. Akita Y, Fujisawa A, Ra S, Miyazaki S. A case of metastatic tumor of the corpus cavernosum penis. Nippon Hinyokika Gakkai Zasshi 1979;70:614.

156. Hayes WT, Young JM. Metastatic carcinoma of the penis. J Chronic Dis 1967;20:891-5.

157. Truc E, Levallois M, Pujol H. Priaprisme par metastase dans les corps caverneux d'un epithelioma bronchique. J Urol (Paris) 1959; 65:93-4.

158. Richter H. Bronchialkarzinon mit Metastasen in einer Zehe und im Penis. Zentralbl Allg Pathol 1953;90:24-8.

159. Staffieri D, Kuruse HA, Levit T. Metastasis raras del cancer de pulmon (in French). Rev Med Rosario 1943;33:24-35.

160. Masson-Lecomte A, Rocher L, Ferlicot S, et al. High-flow priapism due to a malignant glomus tumor (glomangiosarcoma) of the corpus cavernosum. J Sex Med 2011;8:3518-22.

161. López-Aramburu MA, Viguri Díaz A, Rosa Arias J, Peña Pérez P. Penile metastasis like first sign of esophagus carcinoma. Actas Urol Esp 2009;33:318-20.

162. Ozawa H, Muramoto M, Watanabe M. Metastasis to the penis from cecum carcinoma. Int J Urol 2009;16:770.

163. Pai A, Sonawane S, Purandare NC, et al. Penile metastasis from esophageal squamous carcinoma after curative resection. Ann Thorac Cardiovasc Surg 2008;14:238-41.

164. Numakura K, Tadachi K, Shimoda J. A case of metastatic tumor of penis from esophageal carcinoma. Hinyokika Kiyo 2008;54:795-7.

165. Rao S, Arcot R, Pai V, Prathiba D. Disseminated malignant fibrous histiocytoma (giant cell rich): a case report. Indian J Pathol Microbiol 2007;50:795-7.

166. Thyavihally YB, Tongaonkar HB, Gupta S, Gujral S. Primary seminal vesicle adenocarcinoma presenting as isolated metastasis to penis responding to chemotherapy and hormonal therapy. Urology 2007;69:778.

167. Kurul S, Aykan F, Tas F. Penile metastasis of cutaneous malignant melanoma: a true hematogenous spread?: Case report and review of the literature. Melanoma Res 2006;16:259-61.
168. Inamoto T, Azuma $\mathrm{H}$, Iwamoto $\mathrm{Y}$, et al. A rare case of penile metastasis of testicular cancer presented with priapism. Hinyokika Kiyo 2005;51:639-42.

169. Pomara G, Pastina I, Simone M, et al. Penile metastasis from primary transitional cell carcinoma of the renal pelvis: first manifestation of systemic spread. BMC Cancer 2004;4:90.

170. Grimm MO, Spiegelhalder P, Heep H, et al. Penile metastasis secondary to follicular thyroid carcinoma. Scand J Urol Nephrol 2004;38:253-5.

171. Gerber R, Madersbacher S, Fleischmann A, et al. Rare seminoma metastasis to the corpus spongiosum and urethra. Urologe A 2003;42:1491-2.

172. Hattori T, Otani T, Ito Y, Takeda H. A report of two cases of priapism with metastatic penile tumor. Nihon Hinyokika Gakkai Zasshi 2002;93:568-72.

173. Satoh H, Okhi T, Momma T, et al. Penile skin metastasis of gastric carcinoma associated with prostate carcinoma: a case report. Nihon Hinyokika Gakkai Zasshi 2001;92:628-31.

174. Ahn TY, Choi EH, Kim KS. Secondary penile carcinoma originated from pancreas. J Korean Med Sci 1997;12:67-9.

175. Sagar SM, Retsas S. Metastasis to the penis from malignant melanoma: case report and review of the literature. Clin Oncol (R Coll Radiol) 1992;4:130-1.

176. Perez LM, Shumway RA, Carson CC 3rd, et al. Penile metastasis secondary to supraglottic squamous cell carcinoma: review of the literature. J Urol 1992;147:157-60.

177. Baba K, Yajima M, Ohyama N, et al. Metastatic penile tumor from lower pharynx: a case report. Hinyokika Kiyo 1990;36:1467-70.

178. Kakehi Y, Arai E, Katamura E, et al. Metastatic penile tumors: report of three cases. Hinyokika Kiyo 1984;30:363-9.

179. Mishina T, Oe H, Miyagoshi K, et al. Metastatic carcinoma of penis secondary to testicular neoplasm: report of a case. Nihon Hinyokika Gakkai Zasshi 1972;63:57-67.

180. Haas A, Ritter SA. Benign giant-cell tumor of femur with embolic metastasis in prepuce of penis. Am J Surg 1955;89:573-8.

181. Tsanou E, Sintou-Mantela E, Pappa L, et al. Fine-needle aspiration of secondary malignancies of the penis: a report of three cases. Diagn Cytopathol 2003;29:229-32.

182. Morichetti D, Mazzucchelli R, Lopez-Beltran A, et al. Secondary neoplasms of the urinary system and male genital organs. BJU Int 2009;104:770-6.

183. Bertolotto M, Serafini G, Dogliotti L, et al. Primary and secondary malignancies of the penis: ultrasound features. Abdom Imaging 2005;30:108-12.

184. Nakayama F, Sheth S, Caskey CI, Hamper UM. Penile metastasis from prostate cancer: diagnosis with sonography. J Ultrasound Med 1997;16:751-3.

185. Escribano G, Allona A, Burgos FJ, et al. Cavernosography in diagnosis of metastatic tumors of the penis: 5 new cases and a review of the literature. J Urol 1987;138:1174-7.

186. Haddad FS, Kovac A, Kivirand A, Sonkin B. Cavernosography in diagnosis of penile metastases secondary to bladder cancer. Urology 1985;26:585-6.

187. Lau TN, Wakeley CJ, Goddard P. Magnetic resonance imaging of penile metastases: a report on five cases. Australas Radiol 1999; 43:378-81.

188. Kendi T, Batislam E, Basar MM, et al. Magnetic resonance imaging (MRI) in penile metastases of extragenitourinary cancers. Int Urol Nephrol 2006;38:105-9.

189. Yumura Y, Moriyama M, Sasaki T, et al. Carcinoma of penis: report of 59 cases and review of literature. Nihon Hinyokika Gakkai Zasshi 2007;98:819-25.

190. Robey EL, Schellhammer PF. Four cases of metastases to the penis and a review of the literature. J Urol 1984;132:992-4. 